\title{
Assignment of Centers for Disease Control group IVc-2 to the genus Ralstonia as Ralstonia paucula sp. nov.
}

\author{
P. Vandamme, ${ }^{1}$ J. Goris, ${ }^{1}$ T. Coenye, ${ }^{1}$ B. Hoste, ${ }^{2}$ D. Janssens, ${ }^{2}$ K. Kersters, ${ }^{1}$ \\ P. De $\operatorname{Vos}^{1}$ and E. Falsen ${ }^{3}$
}

\begin{abstract}
Author for correspondence: P. Vandamme. Tel: +32926451 13. Fax: +3292645092 .
e-mail: peter.vandamme@rug.ac.be
\end{abstract}

\footnotetext{
1,2 Laboratorium voor Microbiologie, Ledeganckstraat 35 , B-9000 Gent ${ }^{1}$ and BCCM/LMG Culture Collection ${ }^{2}$, University of Ghent, Belgium

3 Department of Clinical Bacteriology, University of Goteborg, S-413 46 Goteborg, Sweden
}

\begin{abstract}
An integrated genotypic and phenotypic analysis of 12 Centers for Disease Control (CDC) group IVC-2 strains revealed that this taxon represents a novel species belonging to the genus Ralstonia. Comparative 165 rDNA sequence analysis allocated a representative CDC group IVC-2 strain to the Ralstonia branch of the $\beta$ subclass of the Proteobacteria. DNA-DNA hybridizations did not detect significant binding levels towards any presently known Ralstonia species, including Ralstonia pickettii. Its DNA base ratio is between 65 and $67 \mathrm{~mol} \%$. The name Ralstonia paucula sp. nov. is proposed, with strain LMG 3244 (= CDC E6793), isolated from a human respiratory tract, as the type strain. R. paucula can be differentiated from other Ralstonia species by wholecell protein analysis, amplified rDNA restriction analysis and a variety of classical biochemical tests. Strains have been isolated from various human clinical and environmental sources.
\end{abstract}

Keywords: CDC group IVc-2, Ralstonia, $\beta$-Proteobacteria

\section{INTRODUCTION}

Centers for Diseases Control (CDC) group IVc-2 is a Gram-negative non-fermentative rod sporadically associated with human infection. Cases of bacteraemia, peritonitis and tenosynovitis have been reported but an underlying disease, potentially affecting the immunocompetency of the patients was described in most cases (Anderson et al., 1997). This bacterium is believed to be an environmental organism and several infections associated with contaminated water have been described (Anderson et al., 1997). CDC group IVc-2 strains have also been reported in pool water (Aspinal \& Graham, 1989), groundwater (Campbell Wyndham et al., 1994), and even in considerable percentages of different brands of bottled mineral water (Manaia et al., 1990).

Although known in scientific literature for a long time, few studies have focussed on the taxonomic affiliation of this organism and a proper binomial name has not

Abbreviation: ARDRA, amplified rDNA restriction analysis.

The GenBank/EMBLDDBJ accession number for the 165 rDNA sequence of strain LMG $3413^{\mathrm{T}}$ is AF085226. been proposed. In 1987, Rossau and colleagues reported that CDC group IVc-2 strains belonged to rRNA superfamily III sensu De Ley or the $\beta$ subclass of the Proteobacteria (De Ley, 1992), with the generically misnamed Alcaligenes eutrophus and Pseudomonas solanacearum as its closest neighbours (Kersters \& De Ley, 1984; Rossau et al., 1987). Later, Yabuuchi et al. (1995) reclassified Alcaligenes eutrophus, Pseudomonas solanacearum and Pseudomonas pickettii in a novel genus Ralstonia, as Ralstonia eutropha, Ralstonia solanacearum and Ralstonia pickettii, respectively. The $T_{\mathrm{m}}(\mathrm{e})$ values of DNA of CDC group IVc-2 strains towards radioactively labelled rRNA of the $R$. eutropha type strain (Rossau et al., 1987) indicate that CDC group IVc-2 belongs to the same genus; this was recently confirmed by $16 \mathrm{~S}$ rDNA gene sequence analysis as reported by Osterhout et al. (1998). In the present study, we performed an integrated genotypic and phenotypic analysis of CDC group IVc-2 strains to characterize their phenotype and genotype, and their relatedness towards established species of the genus Ralstonia. Apart from $R$. pickettii, $R$. solanacearum and $R$. eutrophus, we also included reference strains of $R$. gilardii, a recently delineated species from environmental and human clinical origin (Coenye et al., 1999). 


\section{METHODS}

Bacterial strains and growth conditions. All strains were grown on Trypticase Soy agar (catalogue no. 11768; BBL) and incubated aerobically at about $37^{\circ} \mathrm{C}$, except when stated otherwise.

The strains and their sources are listed in Table 1. Bacteriological purity was checked by plating and examining living and Gram-stained cells.

Analysis of protein electrophoretic patterns. Strains were incubated for $48 \mathrm{~h}$. Preparation of cellular protein extracts, PAGE, densitometric analysis, and normalization and interpolation of the protein profiles were performed as described by Pot et al. (1994); numerical analysis was performed using the GelCompar 4.0 software package (Applied Maths). The profiles were recorded and stored on a PC. The similarity between all pairs of traces was expressed by the Pearson product-moment correlation coefficient converted for convenience to a percentage value.
Amplified rDNA restriction analysis (ARDRA). DNA was prepared and 16S rDNA genes were amplified as described previously for Alcaligenes and Bordetella strains (Heyndrickx et al., 1996) from 24-h-old cells. Restriction digestion of the amplified 16S rDNA was carried out as recommended by the manufacturer using $5 \mathrm{U}$ of one of the restriction enzymes HaeIII (Boehringer Mannheim), RsaI (Pharmacia Biotech), HpaII, TaqI or NlaIV (New England Biolabs). For each strain the normalized restriction patterns obtained with each of the five restriction enzymes were assembled into a combined profile and analysed using the Dice similarity coefficient $\left(S_{\mathrm{D}}\right)$ and the UPGMA clustering algorithm (GelCompar 4.0).

Preparation of high-molecular-weight DNA. Highmolecular-weight native DNA was prepared as described before (Vandamme et al., 1992).

DNA base compositions. All of the mean mol \% guanine plus cytosine $(\mathrm{mol} \% \mathrm{G}+\mathrm{C})$ values were determined by

\section{Table 1. List of strains studied}

${ }^{\mathrm{T}}$ indicates type strain. Abbreviations: API, Appareils et Procédés d'Identification, Marcy-l'Etoile, France; ATCC, American Type Culture Collection, Manassas, VA, USA; CCM, Czech Collection of Microorganisms, Brno, Czech Republic; CCUG, Culture Collection University of Göteborg, Department of Clinical Bacteriology, Göteborg, Sweden; CDC, Centers for Disease Control and Prevention, Atlanta, GA, USA; CIP, Collection bactérienne de l'Institut Pasteur, Paris, France; LMG, BCCM/LMG Culture Collection, Laboratorium voor Microbiologie, Universiteit Gent, Gent, Belgium; NCPPB, National Collection of Plant-pathogenic Bacteria, Harpenden Laboratory, Hertfordshire, UK. Source of isolates are given if known.

\begin{tabular}{|c|c|c|c|}
\hline Strain & Other strain no. & Received from: & Source \\
\hline Ralstonia eutropha LMG $1199^{\mathrm{T}}$ & CCUG $1776^{\mathrm{T}}$, ATCC $17697^{\mathrm{T}}$ & ATCC & Soil (USA, 1957) \\
\hline Ralstonia gilardii LMG $5886^{\mathrm{T}}$ & API $141-2-84^{\mathrm{T}}$, CCUG $38401^{\mathrm{T}}$ & D. Monget & Whirlpool \\
\hline Ralstonia gilardii LMG 3400 & API 119-04-76, CDC D2683 & J. Gayral & Spinal fluid (USA) \\
\hline Ralstonia gilardii LMG 15537 & CCUG 24719 & G. L. Gilardi & Bone marrow (USA) \\
\hline Ralstonia pickettii LMG $5942^{\mathrm{T}}$ & CCUG $3318^{\mathrm{T}}$, Pickett K-288 ${ }^{\mathrm{T}}$ & M. Pickett & Human (USA) \\
\hline Ralstonia pickettii LMG 6871 & CCUG 18841, CCM 2846 & $\mathrm{CCM}$ & Soil (Senegal) \\
\hline Ralstonia pickettii LMG 7001 & CCUG 3314, Pickett K-214 & M. Pickett & Human (USA) \\
\hline Ralstonia pickettii LMG 7002 & CCUG 3316, Pickett K-279 & M. Pickett & Human (USA) \\
\hline Ralstonia pickettii LMG 7005 & CCUG 1467, CDC A5832 & R. Weaver & \\
\hline Ralstonia pickettii LMG 7008 & CCUG 2165 & K. Lincoln & Urine (Sweden, 1973) \\
\hline Ralstonia pickettii LMG 7012 & CCUG 12413, CDC F2780 & D. G. Hollis & Human wound (USA) \\
\hline Ralstonia pickettii LMG 7145 & CCUG 3315, Pickett K-232 & M. Pickett & Human (USA) \\
\hline $\begin{array}{l}\text { Ralstonia solanacearum LMG } \\
2299^{\mathrm{T}}\end{array}$ & NCPPB $325^{\mathrm{T}}$, CCUG $14272^{\mathrm{T}}$ & NCPPB & $\begin{array}{l}\text { Lycopersicon esculentum } \\
\text { (USA) }\end{array}$ \\
\hline Ralstonia paucula LMG $3244^{\mathrm{T}}$ & CDC E6793 ${ }^{\mathrm{T}}$, CCUG $12507^{\mathrm{T}}$ & R. Weaver & $\begin{array}{l}\text { Human, respiratory tract } \\
\text { (USA) }\end{array}$ \\
\hline Ralstonia paucula LMG 3245 & CDC E8967, CCUG 12411 & R. Weaver & Human, sputum (USA) \\
\hline Ralstonia paucula LMG 3317 & CCUG 12446, API 99-7-76 & D. Monget & Human (USA) \\
\hline Ralstonia paucula LMG 3318 & CCUG 12443, API 93-7-76 & D. Monget & Human (USA) \\
\hline Ralstonia paucula LMG 3319 & CCUG 11264 & $\begin{array}{l}\text { PHLS, Gothenborg, } \\
\text { Sweden }\end{array}$ & $\begin{array}{l}\text { Wound newborn } \\
\text { (Sweden, 1981) }\end{array}$ \\
\hline Ralstonia paucula LMG 3320 & CCUG 4424 & $\begin{array}{l}\text { PHLS, Vasteras, } \\
\text { Sweden }\end{array}$ & $\begin{array}{l}\text { Humidifier in nursery } \\
\text { (Sweden, 1975) }\end{array}$ \\
\hline Ralstonia paucula LMG 3413 & CIP 62.31, CCUG 13723 & CIP & \\
\hline Ralstonia paucula LMG 3517 & API 077-07-76, Gilardi 1810 & D. Monget & USA \\
\hline Ralstonia paucula LMG 3518 & API 078-07-76, Gilardi 1913 & D. Monget & USA \\
\hline Ralstonia paucula LMG 15544 & CCUG 24723, Gilardi 5172 & G. L. Gilardi & $\begin{array}{l}\text { Human urine (USA, } \\
\text { 1985) }\end{array}$ \\
\hline Ralstonia paucula $\mathrm{L} 5 \mathrm{~L} 7$ & & M. Da Costa & Mineral water (Portugal) \\
\hline Ralstonia paucula L1L1 & & M. Da Costa & Mineral water (Portugal) \\
\hline
\end{tabular}


thermal denaturation and calculated by using the equation of Marmur \& Doty (1962), as modified by De Ley (1970).

DNA-DNA hybridization experiments. The degree of DNADNA binding, expressed in percentage, was determined spectrophotometrically by the initial renaturation rate method of De Ley et al. (1970). Each value is the mean of at least two hybridization experiments. Values of $30 \%$ DNA binding and less do not represent significant DNA homology. The total DNA concentration was about $62 \mu \mathrm{g} / \mathrm{ml}$, and the optimal renaturation temperature in $2 \times \mathrm{SSC}$ was $81 \cdot 0^{\circ} \mathrm{C}$.

165 rDNA sequencing. Part of the rDNA operon, comprising the nearly complete 16S DNA was amplified by PCR. The forward primer was AGA GTT TGA TCC TGG CTC AG, corresponding to positions 8-27 of the Escherichia coli $16 \mathrm{~S}$ rRNA numbering system. The reverse primer was AAG GAG GTG ATC CAG CCG CA, complementary to positions 1541-1522 of the Escherichia coli 16S rRNA numbering system. PCR amplified 16S rDNAs were purified using the QIAquick PCR Purification Kit (Qiagen). Sequence analysis was performed using an Applied Biosystems 377 DNA Sequencer and the protocols of the manufacturer using the ABI PRISM Dye Terminator Cycle Sequencing Ready Reaction Kit (with AmpliTaq DNA Polymerase, Fs). The sequencing primers were those given by Coenye et al. (1999). Sequence assembly was performed by using the program AutoAssembler (Perkin-Elmer, Applied Biosystems) and phylogenetic analysis was performed by using the GeneCompar 2.0 software package (Applied Maths). The consensus sequence and the sequences of strains belonging to the same phylogenetic group (retrieved from the EMBL database) were aligned and a phylogenetic tree was constructed based on the neighbour-joining method.

Phenotypic tests. Classical phenotypic tests were performed as described previously (De Vos et al., 1985). The API $20 \mathrm{NE}$ and API ZYM microtest systems were used according to the recommendations of the manufacturer (bioMérieux).

\section{RESULTS}

\section{PAGE of whole-cell proteins}

Duplicate protein extracts of several strains were prepared to check the reproducibility of the growth conditions and the preparation of the extracts. The similarity level between duplicate protein patterns was above $93 \%$ (data not shown).

The dendrogram resulting from the numerical analysis of the protein profiles of all of the strains examined is shown in Fig. 1; Fig. 2 shows the whole-cell protein patterns of a representative selection of the strains examined. CDC group IVc-2 strains formed two distinct clusters: a first cluster (cluster IV) grouping above a similarity level of $88 \%$ contained strains LMG 3517, LMG 3518, LMG 15544 and LMG 3413; and a second cluster (cluster V) grouping above a similarity level of $76 \%$, contained strains LMG 3317 , LMG 3318, LMG 3319, LMG 3320, LMG 3244 ${ }^{\mathrm{T}}$, LMG 3245, L5L7 and L1L1. The differences between the whole-cell protein profiles of strains of the two clusters were primarily confined to the position and density of a dense protein band with molecular weight

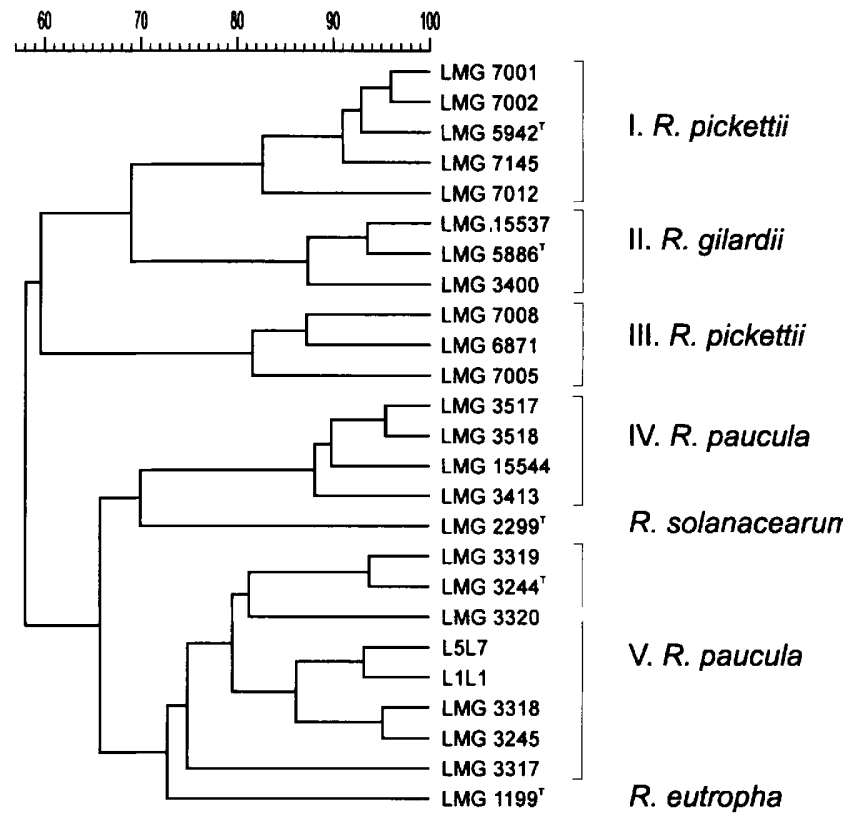

Fig. 1. Dendrogram derived from the unweighted pair group average linkage of correlation coefficients between the wholecell protein patterns of all of the strains studied. Roman numerals are cluster numbers as discussed in the text.
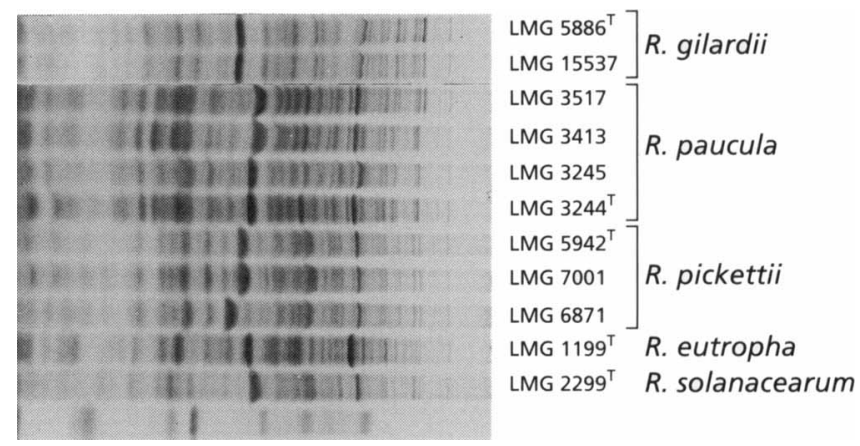

Fig. 2. Whole-cell protein profiles of a representative selection of strains examined. The molecular weight markers used (bottom lane) are indicated from left to right: lysozyme (14500), trypsin inhibitor (20100), trypsinogen (24000), carbonic anhydrase (29000), glyceraldehyde-3-phosphate dehydrogenase (36000), egg albumin (45000) and bovine albumin (66000).

situated in the 29000-36000 molecular weight region (Fig. 2). In addition, some of the strains were characterized by a distortion of part of the protein pattern (compare the patterns of strains LMG 3245 and LMG 3244 in Fig. 2) which was a reproducible phenomenon.

Similarly, $R$. pickettii strains formed two distinct clusters (clusters I and III, grouping above similarity levels of $82 \%$ and $81 \%$, respectively) which were characterized by a different position of a dense protein band with molecular weight situated in the 29000 36000 molecular weight region (compare the patterns 


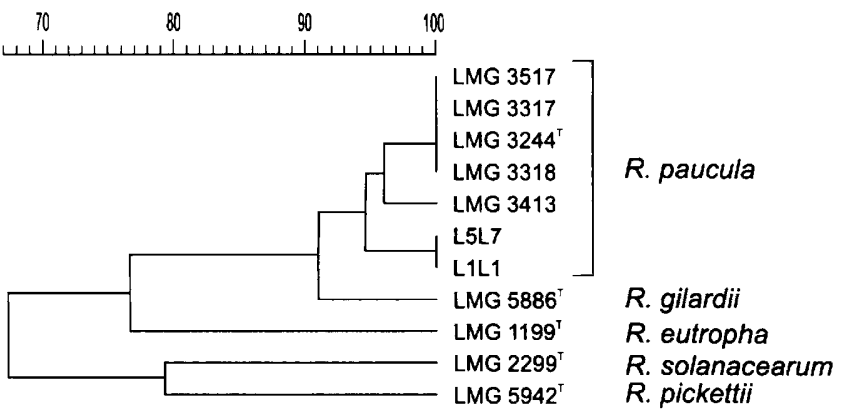

Fig. 3. Dendrogram derived from the unweighted pair group average linkage of Dice similarity coefficients $\left(S_{D}\right)$ between the combined ARDRA patterns of all strains studied.

of strains LMG 6871 and LMG 7001 in Fig. 2). The $R$. gilardii strains (cluster II, grouping above a correlation level of $87 \%$ ) and the type strains of $R$. eutropha and $R$. solanaecearum occupy distinct positions in the dendrogram (Fig. 1).

\section{ARDRA analysis}

Seven CDC group IVc-2 strains were examined along with the type strains of $R$. eutropha, $R$. solanacearum, $R$. pickettii and $R$. gilardii. In the numerical analysis of the combined ARDRA patterns (Fig. 3), all CDC group IVc-2 strains examined formed a single cluster above a similarity level of $95 \%$. All of the type strains of the reference species occupied distinct positions.

\section{DNA base composition}

The DNA G + C content of all of strains examined is given in Table 2 .

\section{DNA-DNA hybridization results}

The DNA-DNA hybridization results are listed in Table 2. Hybridization levels among CDC group IVc2 strains representing both protein electrophoretic

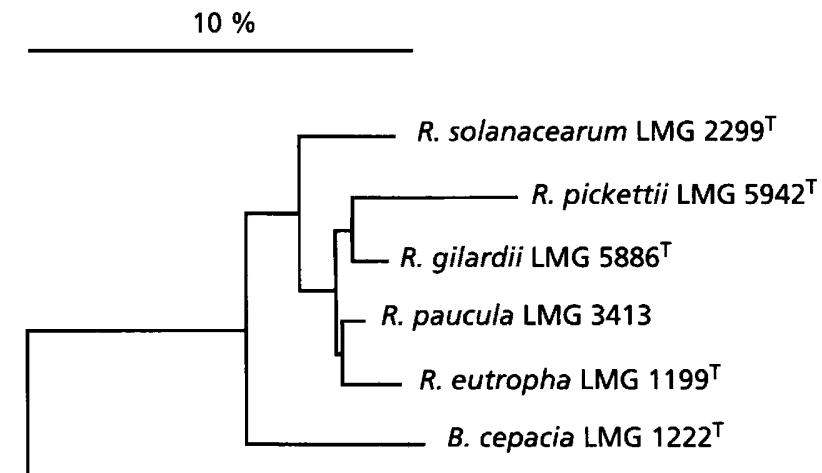

A. faecalis LMG $1229^{\top}$

Fig. 4. Neighbour-joining phylogenetic tree of $R$. paucula LMG 3413 and related bacteria based on 16S rRNA sequence comparisons. Scale bar indicates $10 \%$ sequence dissimilarity.

subclusters were between 67 and $100 \%$. Values of $35 \%$ or less were measured towards and between type strains of Ralstonia reference species.

\section{Phylogenetic analysis of the 16S rDNA sequence}

Sequence similarity values towards $16 \mathrm{~S}$ rDNA sequences of the closest phylogenetic neighbours of $R$. paucula LMG 3413 were: 97.5\%, R. gilardii LMG $5886^{\mathrm{T}}$ (accession no. AF076645); 97.2\%, R. eutropha LMG $1199^{\mathrm{T}}(\mathrm{M} 32021) ; 95.2 \%$ R. pickettii LMG $5942^{\mathrm{T}}$ (X67042); 94.2\% R. solanacearum LMG $2299^{\mathrm{T}}$ (X67036). The similarity levels towards Burkholderia cepacia LMG $1222^{\mathrm{T}}$ (M22518), Alcaligenes faecalis LMG $1229^{\mathrm{T}}$ (M22508), and other representatives of the $\beta$ subclass was below $90 \%$. Fig. 4 . shows the result of neighbour-joining cluster analysis of strain LMG 3413 and related bacteria.

\section{Phenotypic tests}

The results of the phenotypic analyses are listed below; some are shown in Table 3.

Table 2. DNA base ratio and DNA-DNA binding values (\%) of strains examined

\begin{tabular}{|c|c|c|c|c|c|}
\hline Strain & $\begin{array}{c}G+C \text { content } \\
(\mathrm{mol} \%)\end{array}$ & $\begin{array}{l}\text { R. paucula } \\
\text { LMG 3244 }\end{array}$ & $\begin{array}{l}\text { R. paucula } \\
\text { LMG } 3413\end{array}$ & 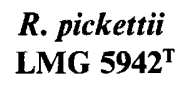 & $\begin{array}{l}\text { R. eutropha } \\
\text { LMG 1199 }\end{array}$ \\
\hline R. paucula LMG $3244^{\mathrm{T}}$ & 67 & 100 & & & \\
\hline R. paucula LMG 3413 & 65 & 82 & & & \\
\hline R. paucula LMG 3517 & & 67 & & & \\
\hline R. gilardii LMG $5886^{\mathrm{T}}$ & 68 & 21 & & & \\
\hline R. pickettii LMG $5942^{\mathrm{T}}$ & 64 & 13 & & 100 & \\
\hline R. eutropha LMG $1199^{\mathrm{T}}$ & 69 & & 24 & 35 & 100 \\
\hline R. solanacearum LMG $2299^{\mathrm{T}}$ & 66 & 16 & & 32 & 2 \\
\hline
\end{tabular}


Table 3. Differential phenotypic characteristics of $R$. paucula and related or similar bacteria

+ , Character is present in all strains; -, character is absent in all strains; $\mathrm{w}$, weakly positive reaction; $\mathrm{v}$, strain-dependent result.

\begin{tabular}{|c|c|c|c|c|}
\hline Character & $R \cdot$ paucula & $R \cdot$ pickettii & R. gilardii & B. bronchiseptica \\
\hline Catalase acitivity & + & - & + & + \\
\hline Oxidase acitivity & + & - & - & + \\
\hline \multicolumn{5}{|l|}{ Growth in the presence of: } \\
\hline $10 \mu \mathrm{g}$ disk of penicillin & - & $\mathrm{w}$ & - & - \\
\hline Tween 80 & + & + & - & - \\
\hline Growth at $42^{\circ} \mathrm{C}$ & + & $\mathrm{w}$ & + & + \\
\hline \multicolumn{5}{|l|}{ Oxidation/fermentation test for: } \\
\hline D-Glucose & - & + & - & - \\
\hline D-Fructose & - & $\mathrm{v}$ & - & - \\
\hline D-Xylose & - & + & - & - \\
\hline Nitrate reduction & - & + & - & + \\
\hline Nitrite reduction & - & + & - & - \\
\hline Denitrification & - & + & - & - \\
\hline Urease activity & + & $\mathrm{v}$ & - & + \\
\hline \multicolumn{5}{|l|}{ Assimilation of: } \\
\hline D-Glucose & - & + & - & - \\
\hline L-Arabinose & - & + & - & - \\
\hline$N$-Acetylglucosamine & - & + & - & - \\
\hline Caprate & + & $\mathrm{w}$ & - & $\mathrm{v}$ \\
\hline Citrate & + & + & - & + \\
\hline Adipate & + & $\mathrm{w}$ & $\mathrm{w}$ & + \\
\hline Phenylacetate & + & w & - & + \\
\hline Alkaline phosphatase activity & + & $\mathrm{w}$ & + & $\mathrm{v}$ \\
\hline Acid phosphatase activity & + & $\mathrm{w}$ & + & $\mathrm{v}$ \\
\hline Esterase $C 4$ activity & + & $\mathrm{w}$ & + & + \\
\hline Cystine arylamidase activity & + & - & - & - \\
\hline Phosphoamidase activity & + & w & $\mathrm{w}$ & - \\
\hline Lipase $\mathrm{C} 14$ activity & + & + & - & - \\
\hline
\end{tabular}

\section{DISCUSSION}

\section{Classification of CDC group IVC-2 strains as a novel Ralstonia species}

Previous studies have demonstrated that CDC group IVc-2 phylogenetically belongs to the genus Ralstonia as demonstrated by $16 \mathrm{~S}$ rRNA sequence analysis and DNA-rRNA hybridization experiments (Rossau et al., 1987; Osterhout et al., 1998). In the present study, we examined the genotypic and phenotypic characteristics of 12 CDC group IVc-2 strains and compared them with those of the presently known species of the genus Ralstonia. The biochemical reactivity pattern, the whole-cell protein and the ARDRA patterns of all strains, including two spa water isolates (Manaia et al., 1990), were very similar and clearly distinct from those of strains representing the known Ralstonia species (Figs 1-3).

Analysis of the nearly complete $16 \mathrm{~S}$ rDNA sequence of strain LMG 3413 revealed sequence similarity values of $94 \cdot 2-97.5 \%$ towards $16 \mathrm{~S}$ rDNA sequences of Ralstonia species; the similarity levels towards Burkholderia or Alcaligenes species, the closest relatives of Ralstonia, were below $90 \%$. This confirmed that CDC group IVc-2 belongs to the genus Ralstonia as it clusters amidst the other named Ralstonia species and it is clearly separated from related genera. The DNA base ratio of about $66 \mathrm{~mol} \%$ is within the range of the genus Ralstonia which is between 64 and $69 \mathrm{~mol} \%$ (Coenye et al., 1999; Yabuuchi et al., 1995), and DNA-DNA hybridizations towards the type strains of $R$. eutropha, $R$. solanacearum, $R$. pickettii and $R$. gilardii revealed no significant DNA-DNA binding levels (Table 2). These data unambiguously indicate that CDC group IVc-2 represents a novel Ralstonia species for which we propose the name Ralstonia paucula sp. nov. below.

\section{Identification of $R$. paucula sp. nov.}

Thus far, two Ralstonia species have been isolated from human clinical specimens. $R$. pickettii is a wellestablished species that has been isolated from various human sources including urine, wounds, blood, cerebrospinal fluid and the nasopharynx (Riley \& Weaver, 1975). $R$. gilardii is a novel species that has been 
isolated from spinal fluid, bone marrow, a furuncle and environmental sources (Coenye et al., 1999). As discussed above, whole-cell protein and ARDRA analyses differentiate $R$. paucula from other Ralstonia species. In addition, phenotypic tests as listed in Table 3 readily allow differentiation of $R$. paucula from the other Ralstonia species. Bordetella bronchiseptica, an organism mainly isolated from respiratory tract infections in man and animals shares many characteristics with $R$. paucula but can be differentiated by its ability to reduce nitrate, inability to grow in the presence of Tween 80, and absence of cystine arylamidase, phosphoamidase and lipase C14 activity (Table 3).

\section{Description of Ralstonia paucula sp. nov.}

Ralstonia paucula (pau'cu.la. L. adj. pauculus rare, very few, to indicate that these strains only sporadically cause human infections).

Cells are Gram-negative, non-spore-forming and rodshaped. After $24 \mathrm{~h}$ growth on Trypticase soy agar at $30^{\circ} \mathrm{C}$, the mean cell size was about $0.8 \mu \mathrm{m}$ in width, and $1 \cdot 2-2 \mu \mathrm{m}$ in length. Strains produce convex, circular, and beige colonies with entire edge and smooth surface. Motile by means of peritrichous flagella. Catalase and oxidase activities are present. Non-pigmented. No haemolysis on horse blood agar. Grows at 30,37 and $42{ }^{\circ} \mathrm{C}$. No acid production from D-glucose, maltose, adonitol, D-fructose, or D-xylose. Growth in the presence of 0.5 and $1.5 \% \mathrm{NaCl}$, but not in the presence of cetrimide, $10 \%$ lactose, penicillin $(10 \mu \mathrm{g}$ disks) or $3,4.5$ or $6 \% \mathrm{NaCl}$. Grows on Drigalski agar. Hydrolyses Tween 80 . No fluorescence on King B medium. Negative for lysine or ornithine decarboxylases and for arginine dihydrolase activity. No amylase activity. Nitrate and nitrite are not reduced. No denitrification. Hydrolysis of urea, but not gelatin or aesculin. No $\beta$-galactosidase or DNase activity. No production of indole. No production of hydrogen sulfide or acid in triple sugar iron agar. No tryptophanase activity. Assimilates D-gluconate, caprate, adipate, L-malate, citrate, phenyl acetate and DL-lactate, but not D-glucose, trehalose, L-arginine, DL-norleucine, L-arabinose, D-mannose, D-mannitol, $\mathrm{N}$-acetyl-D-glucosamine, maltose or sucrose. Alkaline and acid phosphatase, esterase C4, ester lipase C8, lipase $\mathrm{C} 14$, and leucine and cystine arylamidases, and phosphoamidase activity are present; valine arylamidase, trypsin, chymotrypsin, $\alpha$-galactosidase, $\beta$-glucuronidase, $\alpha$ - and $\beta$-glucosidase, $N$-acetyl- $\beta$ glucosaminidase, $\alpha$-mannosidase and $\alpha$-fucosidase activity are not detected.

Ubiquinone-8 was reported to be the respiratory quinone (Ferreira et al., 1996). Strains have been isolated from a variety of human clinical sources including blood, wounds, sputum, urine, eye, throat and peritoneal fluid. In addition, $R$. paucula strains have been isolated from pool water (Aspinal \& Graham, 1989), groundwater (Campbell Wyndham et al., 1994) and bottled mineral water (Manaia et al., 1990 ). It should be noted that $R$. paucula strains were present in bottled mineral water only at the day of bottling; after $7 \mathrm{~d}$ storage, no strains could be recovered, suggesting that they did not survive or were, unlike several other components of the flora of bottled mineral waters, unable to multiply (Ferreira et al., 1996). The DNA G $+C$ content is $65-67 \mathrm{~mol} \%$. The type strain is LMG $3244^{\mathrm{T}}\left(=\mathrm{CCUG} 12507^{\mathrm{T}}=\mathrm{CDC}\right.$ $\mathrm{E} 6793^{\mathrm{T}}$ ), which was isolated from a human respiratory tract in the USA. Its $\mathrm{G}+\mathrm{C}$ content is $67 \mathrm{~mol} \%$. Ralstonia paucula reference strains are available from the BCCM/LMG and CCUG Culture Collections.

We thank D. Dewettinck, R. Coopman, L. Lebbe and K. Engelbeen for excellent technical assistance and are indebted to the Fund for Scientific Research - Flanders (Belgium) for positions as post-doctoral research fellow (P.V.), senior research associate (P.D.V.), and research and personnel grants (K.K.). We thank all depositors of strains listed in Table 1. T.C. acknowledges the support received from the Vlaams Instituut voor Bevordering van Wetenschappelijktechnologisch onderzoek in de Industrie (Belgium) in the form of a bursary for advanced study. We acknowledge the financial support received from the Cystic Fibrosis Trust (United Kingdom) (grant RS15), the Ministerie van de Vlaamse Gemeenschap, Bestuur Wetenschappelijk Onderzoek (Belgium) for a Concerted Research Action, and the Prime Minister's Services - Federal Office for Scientific, Technical and Cultural Affairs (Belgium).

\section{REFERENCES}

Anderson, R. R., Warnick, P. \& Schreckenberger, P. C. (1997). Recurrent CDC group IVc-2 bacteremia in a human with AIDS. J Clin Microbiol 35, 780-782.

Aspinal, S. T. \& Graham, R. (1989). Two sources of contamination of a hydrotherapy pool by environmental organisms. $J$ Hosp Infect 14, 285-292.

Campbell Wyndham, R., Nakatsu, C., Peel, M., Cashore, A., Ng, J. \& Szilagyi, F. (1994). Distribution of the catabolic transposon Tn527I in a groundwater bioremediation system. Appl Environ Microbiol 60, 86-93.

Coenye, T., Falsen, E., Vancanneyt, M., Hoste, B., Govan, J. R. W., Kersters, K. \& Vandamme, P. (1999). Classification of Alcaligenes faecalis-like isolates from the environment and human clinical samples as Ralstonia gilardii sp. nov. Int $J$ Syst Bacteriol 49, 405-413.

De Ley, J. (1970). Re-examination of the association between melting point, buoyant density, and chemical base composition of deoxyribonucleic acid. J Bacteriol 101, 738-754.

De Ley, J. (1992). The Proteobacteria: ribosomal RNA cistron similarities and bacterial taxonomy, pp. 2111-2140. In The Prokaryotes, 2nd edn, vol. 2. Edited by A. Balows, H. G. Trüper, M. Dworkin, W. Harder \& K.-H. Schleifer. Berlin: Springer.

De Ley, J., Cattoir, H. \& Reynaerts, A. (1970). The quantitative measurement of DNA hybridization from renaturation rates. Eur J Biochem 12, 133-142.

De Vos, P., Kersters, K., Falsen, E., Pot, B., Gillis, M., Segers, P. \& De Ley, J. (1985). Comamonas Davis and Park 1962 gen. nov., 
nom. rev. emend., and Comamonas terrigena Hugh 1962 sp. nov., nom. rev. Int J Syst Bacteriol 35, 443-453.

Ferreira, A. C., Morais, P. V., Gomes, C. \& Da Costa, M. D. (1996). Computer-aided comparison of protein electrophoretic patterns for grouping and identification of heterotrophic bacteria from mineral water. $J$ Appl Bacteriol 80, 479-486.

Heyndrickx, M., Vauterin, L., Vandamme, P., Kersters, K. \& De Vos, P. (1996). Applicability of combined amplified ribosomal DNA restriction analysis (ARDRA) patterns in bacterial phylogeny and taxonomy. J Microbiol Methods 26, 247-259.

Kersters, K. \& De Ley, J. (1984). Genus Alcaligenes Castellani and Chalmers 1919, 936 ${ }^{\mathrm{AL}}$. In Bergey's Manual of Systematic Bacteriology, vol. 1, pp. 361-373. Edited by N. R. Krieg \& J. G. Holt. Baltimore: Williams \& Wilkins.

Manaia, C. M., Nunes, O. C., Morais, P. V. \& Da Costa, M. S. (1990). Heterotrophic plate counts and the isolation of bacteria from mineral waters on selective and enrichment media. $J$ Appl Bacteriol 69, 871-876.

Marmur, J. \& Doty, P. (1962). Determination of the base composition of deoxyribonucleic acid from its thermal denaturation temperature. $J$ Mol Biol 5, 109-118.

Osterhout, G. J., Valentine, J. L. \& Dick, J. D. (1998). Phenotypic and genotypic characterization of clinical strains of CDC group IVc-2. J Clin Microbiol 36, 2618-2622.
Pot, B., Vandamme, P. \& Kersters, K. (1994). Analysis of electrophoretic whole-organism protein fingerprints. In Modern Microbial Methods. Chemical Methods in Prokaryotic Systematics, pp. 493-521. Edited by M. Goodfellow \& A. G. O'Donnell. Chichester: Wiley.

Riley, P. S. \& Weaver, R. E. (1975). Recognition of Pseudomonas pickettii in the clinical laboratory : biochemical characterisation of 62 strains. J Clin Microbiol 1, 61-64.

Rossau, R., Kersters, K., Falsen, E., Jantzen, E., Segers, P., Union, A., NehIs, L. \& De Ley, J. (1987). Oligella, a new genus including Oligella urethralis comb. nov. (formerly Moraxella urethralis) and Oligella ureolytica sp. nov. (formerly CDC group IVe): relationship to Taylorella equigenitalis and related taxa. Int $J$ Syst Bacteriol 37, 198-210.

Vandamme, P., Vancanneyt, M., Pot, B. \& 10 other authors (1992). Polyphasic taxonomic study of the emended genus Arcobacter with Arcobacter butzleri comb. nov. and Arcobacter skirrowii sp. nov., an aerotolerant bacterium isolated from veterinary specimens. Int $J$ Syst Bacteriol 42, 344-356.

Yabuuchi, E., Kosako, Y. Yano, I. Hotta, H. \& Nishiuchi, Y. (1995). Transfer of two Burkholderia and an Alcaligenes species to Ralstonia gen. nov.: proposal of Ralstonia pickettii (Ralston, Palleroni and Doudoroff 1973) comb. nov., Ralstonia solanacearum (Smith 1896) comb. nov. and Ralstonia eutropha (Davis 1969) comb. nov. Microbiol Immunol 39, 897-904. 